\title{
Swab Dosing Unit
}

National Cancer Institute

\section{Source}

National Cancer Institute. Swab Dosing Unit. NCI Thesaurus. Code C53504.

A dosing unit equal to the amount of active ing redient(s) contained in a swab. 